Original Article

\title{
Karakteristik Ibu dan Dukungan Suami dengan Partisipasi Ibu Mengikuti Kelas Ibu Hamil
}

\section{Mother Characteristics and Husband's Support with Mother's Participation in Classes for Pregnant Women}

\author{
Arie Maineny*, Nur Endang \\ Poltekkes Kemenkes Palu, Indonesia \\ (arie.maineny@gmail.com)
}

\begin{abstract}
ABSTRAK
Penelitian ini bertujuan untuk menganalisis hubungan karakteristik ibu dan dukungan suami dengan partisipasi ibu dalam kelas ibu hamil di Puskesmas Kecamatan Ujuna. Penelitian analitik desain cross sectional. Populasi seluruh ibu hamil di wilayah Pustu Ujuna. Sampel dalam penelitian ini sebanyak 33 ibu. Instrumen penelitian menggunakan kuesioner. Analisis data bersifat univariat dan bivariat. Analisis bivariat menggunakan uji Chi-Square.. Hasil penelitian menunjukkan bahwa ada hubungan umur dengan partisipasi ibu hamil di wilayah puskesmas pembantu $(\mathrm{p}=0,020)$, ada hubungan pendidikan dengan partisipasi ibu hamil di wilayah puskesmas pembantu. $(\mathrm{p}=0,046)$, ada hubungan paritas dengan partisipasi ibu hamil di Puskesmas pembantu ujuna $(p=0,020)$, ada hubungan antara dukungan suami dengan partisipasi ibu hamil di wilayah puskesmas ujuna pembantu $(p=0,000)$. Terdapat hubungan antara umur, pendidikan, paritas dan dukungan suami dengan partisipasi ibu hamil di wilayah puskesmas pembantu Ujuna.
\end{abstract}

Kata kunci : Karakteristik Ibu, Dukungan Suami, Kelas Ibu Hamil

\section{ABSTRACT}

This study aims to analyze the relationship between maternal characteristics and husband's support with mother's participation in pregnant women's classes at the Ujuna District Health Center. Cross sectional design analytic research. The population of all pregnant women in the Pustu Ujuna area. The sample in this study were 33 mothers. The research instrument used a questionnaire. Data analysis is univariate and bivariate. Bivariate analysis using Chi-Square test. The results showed that there was a relationship between age and participation of pregnant women in the sub-health center area $(p=0.020)$, there was a relationship between education and participation of pregnant women in the sub-health center area. $(p=0.046)$, there is a relationship between parity with the participation of pregnant women in the sub-health center ujuna $(p=0.020)$, there is a relationship between husband's support and the participation of pregnant women in the area of the sub-health center ujuna $(p=0.000)$. There is a relationship between age, education, parity and husband's support with the participation of pregnant women in the sub-health center area

Keywords : Mother's Characteristics, Husband's Support, Maternity Class

\section{https://doi.org/10.33860/jik.v15i4.480}




\section{PENDAHULUAN}

Salah satu program kesehatan yang diharapkan turut berperan dalam menurunkan angka kesakitan dan kematian akibat kehamilan, persalinan dan nifas adalah dengan dibentuknya kelas ibu hamil, kegiatan kelas ibu hamil menggunakan metode pembelajaran salah satunya dengan pembahasan materi Buku Kesehatan Ibu dan Anak. ${ }^{1}$

Kelas ibu hamil menggunakan metode partisipatif interaktif yang disertai dengan praktik seperti ceramah, tanya jawab, peragaan serta curah pendapat diharapkan mampu mengoptimalkan peningkatan pengetahuan dan sikap ibu hamil untuk mempersiapkan calon orangtua dalam menjalani masa kehamilan, persalinan, perawatan bayi baru lahir dan pola asuh sebagai orang tua. ${ }^{2}$ Beberapa faktor yang mempengaruhi partisipasi ibu dalam mengikuti kelas ibu hamil diantaranya karakteristik ibu yang meliputi umur, pendidikan, dan paritas. ${ }^{3}$

Berdasarkan penelitian yang dilakukan oleh Windari, dkk tahun 2017 dengan judul hubungan karakteristik ibu dan dukungan sosial suami dengan keikutsertaan senam hamil di desa pandanmulyo bahwa terdapat hubungan baik antara usia ibu dengan keikutsertaan kegiatan senam hamiil. Dalam hal ini sebagian besar dari ibu hamil dengan usia 20-35 tahun memiliki hasil yang tinggi terhadap keikutsertaan senam hamil yang mana ibu mengetahui akan pentingnya kebutuhan dari kesehatannya selama masa kehamilan berlangsung. ${ }^{4}$ Bertambahnya umur seseorang akan berpengaruh terhadap perubahan pada aspek psikis dan psikologis (mental). Pada aspek psikologis dan mental taraf berfikir seseorang semakin matang dan dewasa sehingga pola pikir terhadap kehamilannya bisa berubah. $^{5}$

Semakin tinggi tingkat pendidikan maka semakin tinggi pula tingkat pengetahuannya. Pendidikan akan berpengaruh terhadap cara berfikir dalam pengambilan keputusan seseorang untuk menggunakan pelayanan kesehatan. ${ }^{6}$ Ibu hamil dengan berpendidikan tinggi cenderung memiliki pola pikir yang baik dalam memahami informasi-informasi kesehatan, sehingga ibu hamil dengan pendidikan tinggi akan lebih sadar dan merasa perlu untuk mencari informasi kesehatan secara mandiri yang penting bagi dirinya saat menghadapi kehamilan dan cenderung akan lebih memilih ke pelayanan kesehatan yang lebih tinggi. ${ }^{7}$
Ibu yang baru pertama kali hamil merupakan hal yang sangat baru sehingga termotivasi dalam peningkatan kesehatan kehamilannya, sebaliknya ibu yang sudah pernah melahirkan lebih dari satu orang mempunyai anggapan bahwa ia sudah berpengalaman. ${ }^{8}$

Program kelas ibu hamil ini sangatlah bermanfaat, sejalan dengan hasil penelitian Fuada N (2014) yang mengevaluasi program kelas ibu hamil (KIH), bahwa indikator capaian pelaksanaan KIH dapat dilihat pada indikator input, proses dan output seperti berubahnya pengetahuan dan perilaku dan sikap ibu hamil. ${ }^{9}$ Begitu pula penelitian Hastuti (2011) selain efektif meningkatkan pengetahuan, sikap, keterampilan $\mathrm{KIH}$ juga dapat membantu meningkatkan capaian kunjungan K4. Selain itu kelas ibu hamil juga membantu ibu memilih keputusan terhadap kesehatannya. Banyaknya manfaat program kelas ibu hamil sangatlah penting untuk dilakukan oleh ibu hamil secara berkesinambungan. ${ }^{10}$

Di kota Palu jumlah kelas ibu hamil pada tahun 2015 sebanyak 437 kelas dengan jumlah ibu hamil yang aktif mengikuti kelas ibu sebanyak 6.075 jiwa. Pada tahun 2016 jumlah kelas ibu hamil mengalami peningkatan yaitu 447 kelas, namun jumlah ibu hamil yang mengikuti kelas ibu hamil yang mengalami penurunan yaitu sebanyak 4.465 jiwa dari jumlah ibu hamil sebanyak 53.881 jiwa. ${ }^{11}$ Puskesmas Kamonji merupakan pusat pelayanan kesehatan masyarakat dengan jumlah penduduk 53.881 jiwa dan cakupan 7 Kelurahan dengan fasilitas pelayanan 5 Puskesmas Pembantu (Pustu) yaitu Pustu Ujuna, pustu Kobonena, Pustu Lere, Pustu Baru, Pustu Kamonji dan 7 Poskesdes serta 21 Bidan PNS dan 5 Bidan PTT. ${ }^{12}$

Berdasarkan data kunjungan Puskesmas Kamonji tahun 2016 jumlah kelas ibu hamil yang terbentuk pada Puskesmas Kamonji sebanyak 14 kelas, dimana kunjungan kelas ibu hamil tertinggi berada dikeluran Kamonji dengan cakupan $190(86,4 \%)$ ibu hamil dari jumlah ibu hamil sebanyak 220 ibu hamil. Kunjungan terendah berada di Pustu Ujuna dengan jumlah kunjungan sebanyak 108 $(51,4 \%)$ ibu hamil dengan jumlah ibu hamil 210. (Puskesmas Kamonji Tahun, 2016). Data tahun 2017 kunjungan kelas ibu hamil tertinggi berada di Pustu Kamonji dengan jumlah kunjungan kelas ibu hamil sebanyak 153 (84\%) ibu hamil dari jumlah ibu hamil sebanyak 182 
ibu hamil. Kunjungan terendah berada di Pustu Ujuna dengan jumlah kunjungan sebanyak 98 $(51,8 \%)$ ibu hamil dengan jumlah ibu hamil 189 ibu hamil, ini menunjukan bahwa masih rendahnya partisipasi ibu dalam mengikuti kelas ibu hamil.

Perkembangan dan pemanfaatan kelas ibu hamil masih rendah, sementara kelas ibu hamil sangat bermanfaat bagi ibu hamil secara fisik maupun mental. Partisipasi ibu diantaranya dipengaruhi oleh karakteristik ibu yang meliputi umur, pendidikan, dan paritas merupakan faktor prediktor dari hambatan dalam kelas ibu hamil serta dukungan sosial yang juga turut mempengaruhi partisipasi ibu, maka peneliti tertarik untuk meneliti hubungan karakteristik ibu dan dukungan suami dengan partisipasi ibu hamil dalam mengikuti kelas ibu hamil.

\section{METODE PENELITIAN}

Jenis penelitian yang digunakan adalah penelitian analitik dengan pendekatan cross sectional. Populasi dalam penelitian ini adalah seluruh ibu hamil yang berada diwilayah Pustu Ujuna. Sampel adalah bagian dari sejumlah karakteristik yang dimiliki oleh populasi yang digunakan untuk penelitian. Cara pengambilan sampel yang digunakan dalam penelitian ini adalah proposive sampling. Sampel dalam penelitian ini berdasarkan kriteria yang telah ditentukan oleh peneliti. Kriteria inklusi : a) Ibu hamil dengan usia kehamilan 12-42 minggu (trimester 2 dan trimester 3), b) Ibu hamil yang datang pada saat kelas ibu hamil. Kriteria eksklusi : ibu hamil yang tidak memiliki buku KIA.

Penelitian dilaksanakan pada $14-16$ Agustus 2017 di Puskemas Pembantu Ujuna. Penelitian ini menggunakan alat pengambilan data berupa kuesioner. Pada variabel dukungan suami menggunakan Skala Likert dengan pernyataan sebanyak 24 item, terdiri dari pernyataan positif yaitu 24 item. Alternatif jawaban pernyataan positif yaitu Sangat Sering (SS) mendapatkan skor 5, Sering (S) mendapatkan skor 4, Jarang (J) mendapatkan skor 3, Tidak Pernah (TP) 2, dan Sangat Tidak Pernah (STP) mendapatkan skor 1.

Analisis data yaitu uji statistika chi square $\left(x^{2}\right)$. Nilai kemaknaan 0,05 dengan tingkat kepercayaan $95 \%$.

\section{HASIL}

Tabel 1 dapat dilihat bahwa umur ibu pada usia berisiko (57,6\%), dan tidak berisiko $(42,4 \%)$. Pendidikan ibu, sebagian besar berada pada jenjang pendidikan tinggi yaitu 60,6\% . Jarak kehamilan atau paritas ibu sebagian besar adalah Primipara $(57,6 \%)$ dan Multipara $(42,4 \%)$. Dilihat dari dukungan suami sebanyak $52,5 \%$ yang mendukung, dan $48,5 \%$ yang tidak mendukung. Ibu yang berpartisipasi dalam mengikuti kelas ibu hamil sebanyak 51,5\% yang tidak berpartisipasi, dan $48,5 \%$ yang ikut berpartisipasi dalam kelas ibu hamil

Tabel 1. Distribusi frekuensi responden berdasarkan Umur, pendidikan, paritas ibu, dukungan suami dan partisipasi ibu dalam mengikuti kelas ibu hamil

\begin{tabular}{lcc}
\hline Karakteristik & $\mathrm{n}$ & $\%$ \\
\hline Umur Ibu & & \\
Tidak berisiko & 14 & 42,4 \\
Berisiko & 19 & 57,6 \\
Pendidikan Ibu & & \\
Rendah (SD s/d SMP) & 13 & 39,4 \\
Tinggi (SMA s/d PT) & 20 & 60,6 \\
Paritas Ibu & & \\
Primipara & 19 & 57,6 \\
Multipara & 14 & 42,4 \\
Dukungan Suami & & \\
Tidak Mendukung & 16 & 48,5 \\
Mendukung & 17 & 51,5 \\
Partisipasi Ibu Mengikuti & & \\
Kelas Ibu Hamil & & \\
Tidak Berpartisipasi & 17 & 51,5 \\
Berpartisipasi & 16 & 48,5 \\
Total & 33 & 100 \\
\hline
\end{tabular}

Tabel 2 menunjukkan bahwa ada hubungan yang signifikan antara umur ibu, Pendidikan, paritas, dan dukungan suami dengan partisipasi ibu mengikuti kelas ibu hamil dengan nilai p.value $<0,05$. Umur sangat berpengaruh terhadap tinggi rendahnya partisipasi ibu hamil dalam mengikuti kelas ibu hamil. Umur mempengaruhi taraf berfikir ibu dalam menentukan keputusan dan tindakan yang harus dilakukan. Hasil penelitian menunjukan bahwa ibu dengan pendidikan tinggi lebih banyak berpartisipasi dibandingkan dengan ibu yang pendidikan rendah. Ibu yang berpendidikan tinggi cenderung memiliki pola pikir yang baik dalam memahami informasiinformasi kehamilan, sehingga akan lebih sadar dan merasa perlu untuk mencari informasi kesehatan secara mandiri yang penting bagi dirinya. Ibu dengan paritas primipara banyak yang partisipasi kelas ibu hamil karena ibu yang pertama kali hamil lebih ingin meningkatkan 
kesehatan kehamilannya dan juga memiliki keinginan yang kuat untuk menjadi orang tua yang baik. Dukungan suami merupakan faktor penentu dalam pengambilan keputusan wanita dalam mengikuti kelas ibu hamil. Dukungan keluarga termasuk didalamnya dukungan suami terhadap istri yang baik akan semakin meningkatkan sikap dan perilaku orang lain kearah positif dalam hal ini perilaku ibu

Tabel 2 Hubungan karakteristik ibu, dan dukungan suami, dengan partisipasi ibu mengikuti kelas ibu hamil

\begin{tabular}{|c|c|c|c|c|c|c|}
\hline & \multicolumn{4}{|c|}{ Partisipasi } & \multirow{3}{*}{ Total } & \multirow{3}{*}{$P$ value } \\
\hline & \multicolumn{2}{|c|}{$\mathrm{Ya}$} & \multicolumn{2}{|c|}{ Tidak } & & \\
\hline & $\mathrm{n}$ & $\%$ & $\mathrm{n}$ & $\%$ & & \\
\hline \multicolumn{7}{|l|}{ Usia Ibu } \\
\hline Tidak berisiko & 3 & 21 & 11 & 79 & \multirow[t]{2}{*}{14} & \multirow{2}{*}{0,020} \\
\hline Berisiko & 13 & 68 & 6 & 32 & & \\
\hline \multicolumn{7}{|l|}{ Pendidikan Ibu } \\
\hline Rendah (SD s/d SMP) & 3 & 21 & 10 & 79 & 13 & \multirow{2}{*}{0,046} \\
\hline Tinggi (SMA s/d PT) & 13 & 68 & 7 & 32 & 20 & \\
\hline \multicolumn{7}{|l|}{ Paritas Ibu } \\
\hline Primipara & 13 & 68 & 6 & 32 & 19 & \multirow{2}{*}{0,020} \\
\hline Multipara & 3 & 21 & 11 & 79 & 14 & \\
\hline \multicolumn{7}{|l|}{ Dukungan Suami } \\
\hline Tidak Mendukung & 1 & 6 & 15 & 94 & 16 & \multirow{3}{*}{0,000} \\
\hline Mendukung & 16 & 94 & 11 & 6 & 17 & \\
\hline Total & 17 & 52 & 16 & 48 & 33 & \\
\hline
\end{tabular}

\section{PEMBAHASAN}

\section{Umur Ibu}

Hasil analis data terdapat hubungan yang signifikan antara umur ibu dengan partisipasi mengikuti kelas ibu hamil di Puskesmas Pembantu Ujuna. Umur sangat berpengaruh terhadap tinggi rendahnya partisipasi ibu hamil dalam mengikuti kelas ibu hamil. Umur mempengaruhi taraf berfikir ibu dalam menentukan keputusan dan tindakan yang harus dilakukan. Semakin bertambahnya umur pola pemikiran menjadi lebih dewasa dalam setiap pengambilan keputusan. Hal ini didukung dengan teori ${ }^{5}$, bertambahnya umur seseorang akan berpengaruh terhadap perubahan pada aspek psikis dan psikologis (mental). Pada aspek psikologis dan mental taraf berfikir seseorang semakin matang dan dewasa sehingga pola pikir terhadap kehamilannya bisa berubah. Hasil penelitian ini sesuai dengan penelitian sebelumnya yang dilakukan oleh Ermiyanti, dkk tahun 2017 bahwa kesadaran pada pasangan usia subur untuk hamil pada rentang usia aman sudah diterapkan oleh masyarakat dan setiap ibu hamil tetap mengikuti kegiatan kelas ibu hamil yang diadakan di wilayah tempat tinggalnya. ${ }^{13}$ Diperkuat dengan penelitian yang dilakukan oleh meilani (2010) bahwa pada hasil tabulasi silang didapatkan tingkat pengetahuan ibu tentang materi kelas ibu hamil berdasarkan karakteristik umur di Puskesmas Tegalrejo didapatkan ibu hamil dengan usia $<20$ tahun sebanyak $3(3 \%)$ responden dengan kategori tingkat pengetahuan baik, dan dari $22 \mathrm{ibu}$ hamil dengan umur 20-35 tahun sebanyak 18 (60\%) responden, dan semua ibu hamil dengan umur 35 tahun sebanyak $5(16,7 \%)$ responden. ${ }^{14}$

\section{Pendidikan Ibu}

Hasil analis data terdapat hubungan yang signifikan antara pendidikan ibu dengan partisipasi mengikuti kelas ibu hamil di Puskesmas Pembantu Ujuna. Hasil penelitian menunjukan bahwa ibu dengan pendidikan tinggi lebih banyak berpartisipasi dibandingkan dengan ibu yang pendidikan rendah. Hal ini sesuai dengan teori Lapau B 2015 bahwa ibu hamil yang berpendidikan tinggi cenderung lebih mudah menyerap dengan baik informasi lebih baik, dibandingkan dengan pendidikan rendah sehingga orang yang berpendidikan tinggi akan lebih sadar dan merasa perlu untuk mencari informasi kesehatan secara mandiri yang penting bagi dirinya. ${ }^{15}$ Penelitian ini sejalan dengan evaluasi yang dilakukan oleh Lapalulu LS bahwa sebagian besar ibu hamil yang mempunyai pendidikan menengah, cenderung aktif dalam mengikuti kelas ibu hamil, yakni sebanyak 19 orang $(50,0 \%)$. Semakin tinggi tingkat pendidikan ibu hamil, maka cenderung semakin aktif pula dalam kegiatan kelas ibu hamil. ${ }^{16}$ Penelitian ini sesuai dengan penelitian yang dilakukan oleh 
Widiantari (2015) menyatakan bahwa ada hubungan yang signifikan antara pendidikan ibu dengan ; partisipasi ibu mengikuti kelas ibu hamil. Hal ini disebabkan orang yang berpendidikan tinggi cenderung memiliki pola pikir yang baik dalam memahami informasiinformasi kesehatan dengan teknologi yang berkembang pesat juga memudahkan seseorang untuk mengakses informasi kesehatan sehingga pendidikan formal tidak lagi menjadi faktor yang utama terkait pengetahuan kesehatan ibu dan anak. ${ }^{17}$ Pendidikan umumnya juga terkait dengan bagaimana indera lebih cepat menanggap berbagai informasi, dan pada umumnya informasi yang diberikan secara langsung lebih mudah diterima. Hal ini sesuai penelitian yang dilakukan oleh Kovala $\mathrm{S}$ bahwa sebagian besar responden $(47,5 \%$, menunjukkan bahwa preferensi menghadiri sesi pendidikan prenatal tatap muka. Pilihan kedua adalah pendekatan kombinasi menghadiri sesi pendidikan prenatal tatap muka dan menerima informasi secara online $(37,0 \%$,). Dan hanya $(6,6 \%)$ responden menunjukkan bahwa mereka lebih suka menerima informasi pendidikan secara online. ${ }^{18}$

\section{Paritas Ibu}

Hasil anilisis data menunjukan nilai p.value $0,020=(0,020<\alpha=0,05)$ bahwa ada hubungan yang signifikan antara paritas ibu dengan partisipasi ibu mengikuti kelas ibu hamil. Hasil penelitian menunjukan bahwa ibu dengan paritas primipara banyak yang partisipasi kelas ibu hamil karena ibu yang pertama kali hamil lebih ingin meningkatkan kesehatan kehamilannya dan juga memiliki keinginan yang kuat untuk menjadi orang tua yang baik. Sedangkan paritas multipara banyak yang tidak berpartisipasi dikarenakan ibu merasa sudah memiliki pengalaman melahirkan yang lalu. Hasil penelitian ini sejalan dengan penelitian yang telah dilakukan Impartina dengan judul hubungan paritas dengan partisipasi mengikuti senam hamil didapatkan hasil nilai $p$ value 0,000 , artinya ada hubungan antara paritas ibu dengan keikutsertaan senam hamil. Dapat disimpulkan bahwa ibu hamil yang memiliki paritas atau jumlah anak yag banyak akan mempengaruhi keikutsertaan ibu hamil dalam mengikuti kelas ibu hamil ataupun senam hamil. Keikutsertaan ibu hamil dalam kelas ibu hamil diketahui mampu memberikan peningkatan pengetahuan ibu hamil dalam merawat kehamilan, menyambut kelahiran bayi dan memberikan pengetahuan terhadap ibu pasca melahirkan ${ }^{19}$.

\section{Dukungan Suami}

Hasil analisa data didapatkan ada hubungan dukungan suami dengan partisipasi ibu mengikuti kelas ibu hamil di Puskesmas Pembantu Ujuna. Dalam penelitian ini menunjukan bahwa mayoritas dukungan suami memiliki dukungan yang tinggi hal tersebut disebabkan responden mendapatkan dukungan yang bebas yang diberikan suami kepada respoden untuk mengikuti kelas ibu hamil. Dukungan suami merupakan faktor penentu dalam pengambilan keputusan wanita dalam mengikuti kelas ibu hamil. Hal ini sejalan dengan teori Suarayasa K menyatakan bahwa semakin tinggi dukungan keluarga termasuk didalamnya dukungan suami terhadap istri maka akan semakin meningkatkan sikap dan perilaku orang lain kearah positif dalam hal ini perilaku ibu untuk berpartisipasi dalam mengikuti kelas ibu hamil. ${ }^{20}$ Penelitian ini sejalan dengan penelitian yang dilakukan oleh Lestari bahwa ada hubungan yang signifikan antara dukungan suami dengan keikutsertaan ibu hamil dalam mengikuti kelas ibu hamil dengan hasil $p$ value $=0.000$, maka dapat disimpulkan ada hubungan dukungan keluarga dengan keikutsertaan kelas ibu hamil di wilayah kerja Puskesmas Kampar Kiri Tengah Kabupaten Kampar, hal ini disebabkan karena suami memberikan dukungan dan kebebasan yang tinggi kepada istri untuk memilih mendapatkan informasi dari mana saja salah satunya dengan mengikuti kelas ibu hamil. ${ }^{7}$ Penelitian lain dilakukan oleh Mertasari Luh menyatakan bahwa ada hubungan dukungan suami dengan partisipasi ibu mengikuti kelas ibu hamil. Ibu yang suaminya mendukung memiliki peluang untuk berpatisipasi 2 kali lebih besar dibandingkan dengan ibu yang tidak mendapatkan dukungan dari suami. ${ }^{21}$

\section{KESIMPULAN DAN SARAN}

Berdasarkan hasil penelitian yang telah dilaksanakan di puskesmas pembantu ujuna, maka dapat disimpulkan bahwa: ada hubungan umur, pendidikan, paritas dan dukungan suami dengan partisipasi ibu mengikuti kelas ibu hamil di Puskesmas Pembantu Ujuna.

Bagi Puskesmas Pembantu Ujuna dapat meningkatkan kunjungan kelas ibu hamil dengan terus mensosialisasikan kelas ibu hamil secara menyeluruh dengan bahasa yang mudah 
dimengerti oleh ibu hamil karena masih banyak ibu hamil dengan umur yang relatif muda, pendidikan yang rendah, dan pengalaman melahirkan yang masih kurang. Bagi ibu hamil dapat berpartisipasi secara aktif dalam kegiatan kelas ibu hamil sehingga dapat menambah pengetahuan dan keterampilan dalam mendeteksi secara dini adanya tanda bahaya selama kehamilan. Bagi peneliti selanjutnya dapat melanjutkan dan mengembangkan penelitian dengan variabel berbeda seperti dukungan tenaga kesehatan, pengetahuan, dan sikap.

\section{DAFTAR PUSTAKA}

1. Kemenkes RI. Pedoman Pelaksanaan Kelas Ibu Hamil Kemenkes RI 2009-2011. Kementrian Kesehatan RI. 2014. p. 1-26.

2. Leerlooijer JN, Bos AE, Ruiter RA, Van Reeuwijk MA, Rijsdijk LE, Nshakira N, et al. Qualitative evaluation of the Teenage Mothers Project in Uganda: A community-based empowerment intervention for unmarried teenage mothers. BMC Public Health. 2013;13(1):1-15.

3. Fitri M, Serudji J, Yetti H. Relationship of Mother Characteristics, Support Support and The Role of The Bidan With Mother's Participation Following The Pregnant Woman Class. Journal of Midwifery. 2018;3(2):65.

4. Windari EN, Putri R, Astriani SN. Hubungan Karakteristik Ibu (Usia, Paritas, Pendidikan) Dan Dukungan Sosial Suami Dengan Keikutsertaan Senam Hamil Di Desa Pandanmulyo. Journal Of Issues In Midwifery. 2018;2(3):30-40.

5. Yudrik J 2011. Psikologi Perkembangan. Prenadamedia Group. Jakarta

6. Agustini Aat 2014. Promosi Kesehatan. Deepublish. Yogyakarta

7. Lestari TA, Susanti A, Fathunikmah. FaktorFaktor Yang Berhubungan Dengankeikutsertaan Ibu Hamil Dalam Mengikut Kelas Ibu Hamil Di Wilayah Kerja Puskesmas Kampar Kiri Tengah Kabupaten Kampar. Jurnal Ibu dan Anak. 2018;6(2):1129.

8. Desmarlyenti D, Hartati S. Faktor Yang Berhubungan Dengan Keikutsertaan Ibu Hamil Dalam Kelas Ibu Hamil. Photon: Jurnal Sain dan Kesehatan. 2019;9(2):114-22.

9. Fuada N, Setyawati B. Pelaksanaan Kelas Ibu Hamil Di Indonesia. Jurnal Kesehatan Reproduksi. 2016;6(2):67-75.

10. Mustofa LA, Nakamnanu MS, Pratika Y, Kurniati DE, Julyanti EM. Kelas Ibu Hamil untuk Memantau Capaian Kunjungan K4 (KEMILAU KUPAT) Sebagai Intervensi
Inovatif dalam Upaya Meningkatkan Derajat Kesehatan Ibu dan Anak di Desa Bulu Kecamatan Purwoasri Kabupaten Kediri. Prosiding Senias. 2019;4:10-7.

11. Dinas Kesehatan Sulawesi Tengah. Profil Kesehatan Sulawesi Tengah Tahun 2016. 2016;70-1.

12. Dinkes Kota Palu. Profil Kesehatan Kota Palu 2018. Journal of Chemical Information and Modeling. 2018;53(9):1689-99.

13. Emiyanti, Rahfiludin MZ, Winarni S. Analisis Faktor-Faktor Yang Berhubungan Dengan Keikutsertaan Kelas Ibu Hamil Januari-Juli Tahun 2017. Jurnal Kesehatan Masyarakat (ejournal). 2017;5(4):801-11.

14. Emy SF dan Y. Journal of Health (JoH) Vol.2 No.2 Juli 2015. 2015;2(2):52-7.

15. Lapau Buchari. 2015. Metodologi Penelitian Kebidanan_Lapau Buchari. Yayasan Pustaka Obor Indonesia. Jakarta

16. Lapalulu LS. Evaluasi pelaksanaan kelas ibu hamil di wilayah kerja puskesmas landawe kabupaten konawe utara tahun 2018. 2018;1121.

17. Widiantari N. Hubungan karakteristik ibu dan dukungan sosial suami dengan partisipasi ibu mengikuti kelas ibu hamil di kota denpasar. Thesis. 2015; Program Pascasarjana Universitas Udayana Denpasar

18. Kovala S, Cramp AG, Xia L. Prenatal Education: Program Content and Preferred Delivery Method From the Perspective of the Expectant Parents. The Journal of Perinatal Education. 2016;25(4):232-41.

19. Impartina Atiul. Hubungan Paritas Dengan Partisipasi Ibu Hamil Mengikuti Senam Hamil. Angewandte Chemie International Edition, 6(11), 951-952. 1967;09(02):44-8.

20. Suarayasa K. 2020. Strategi Menurunkan AKI di Indonesia. Deepublish. Yogyakarta.

21. Sawan DI, Buleleng K. Jurnal Kesehatan MIDWINERSLION. 2019;4(2):101-6. 